広場 Short note ーリケジョ de本音一

\title{
「男女共同参画」社会に向けて 一大学・高専での経験と取組みからー
}

Toward the Society of "Gender Equality"

- From Experiences and Efforts in University and KOSEN -

\section{谷口功”}

Isao TANIGUCHI

今日の激動する社会では，多様性を持ったしなやかな 社会構造が活力ある社会の維持発展に不可欠です，男女 共同参画はその根幹の一つで, 性別に関わりなく個々人 の個性と能力を十分に発揮できる社会になることが望ま れます。とは言え，社会で活躍する女性の占める割合に 関して, 我が国は, 残念ながら世界の中で後塵を扯して いることが様々なデー夕に示されています，大学や高等 専門学校 (高専) の上うな高等教育機関においても, 女 性の教育・研究者の割合は, ヨーロッパ諸国などに比べ てはるかに少なくなっています。

例えば,「学術の動向」21巻10号（2016）には，高等 教育分野での男女格差は，世界145力国中の106位と記載 されています。我が国の科学技術・学術分野に打ける女 性研究者の割合は, 特に, 工学 (13.6\%) 分野で少ない のが目立っています。一方, 産業界からも, 今後の社会 の発展のためには, 女性の視点からの研究・開発が今後 益々重要になっていると扮聞きしています.

筆者が, 国立大学協会・副会長として, 男女共同参画 担当をしていた際（平成26年）には，女性教員比率が 17 \%以上（国立大学協会の当時の目標は $17 \%$ であった）の 国立大学は, 86大学の中で 42 大学 $(49 \%), 15 \%$ 以上は 58大学 $(67 \%)$ で, 全大学の女性教員数の比率は $15.4 \%$, 大学別の女性教員比率の平均では $16.8 \%$ でした（国立大 学に抢ける男女共同参画の実施に関する第12回追跡調查 報告書)。当時, 筆者は熊本大学長として, 女性副学長の 選任や地域の男女共同参画事業の推進にも取り組んでい ました，その後, 平成28年 1 月の政府の閣議決定（平成 28～32年までの計画）もあり, 国立大学の女性教員増加 目標（平成28年 1 月報告書）やアクションプランでは, 新規採用者は自然科学系全体で $30 \%$ （理学系：20\%；工 学系 $15 \%$; 農学系 $30 \%$; 医学・歯学・薬学系合わせて 30 \%）を速やかに実現するとされています。また，女性教 員比率の達成目標を現在の数字の $10 \%$ 増を目指すとも記 載されています. 総力を結集してこれらの数值目標の早 期達成に向けた努力が必要です。

一方, 独立行政法人国立高等専門学校機構（高専機構） が設置する全国にある51の高専には, 平成29年の場合, 女子学生が本科には $19.8 \%$ （女子学生数は, 学科別では,

2018 年 11 月 1 日受付

※ 1 国立高等専門学校機構
化学生物系 $>$ 建築系 $>$ 情報系 $>$ 商船系 $>$ 電気・電子系 $>$ 機械・材料系などの順), 専攻科には $11.5 \%$ 在籍していま す．女子学生が $20 \%$ 超えている高専は 20 校あります. これに対して, 女性教員は（平成27年実績）高専全体で は $10 \%$ 弱で, その内, 教授職に有るものは $4.0 \%$ (平成 28 年には $4.5 \%$ ）です。高専単位で見ると，女性教員が $10 \%$ 以上の高専は, 沖縄, 富山, 鈴鹿, 宇部, 大島商船, 仙 台, 熊本など 26 校, 5 〜 $10 \%$ が 23 校, $5 \%$ 以下が 2 校で す。

高専機構は, 平成 $27 \sim 32$ 年の計画期間に, 国の支援の もと「ダイバーシティ研究環境実現イニシアティブ（特 色型)」を実施して, 平成 26 年 5 月時点で $8.6 \%$ であった 女性教員の割合を $11.3 \%$ 以上に上げるとしています。同 様に教授は $5.5 \%$ にとの目標を持って取り組んでいます. また，管理職職員の育成にも取り組み，現在，ようやく 2 校に女性校長を実現し, 別の 2 校には女性事務部長を 実現しています。この取組みでは, 男女共同参画社会の 実現に向け，1）教育活動全般を通じた男女共同参画の 推進, 2) 教育・研究・就業に打ける男女共同参画の推 進, 仕事と生活の調和（ワーク・ライフ・バランス）を 罒るための環境整備，3）男女共同参画の意識啓発，4） 法人・学校運営に打ける意思決定への男女共同参画の推 進，などを定めています。また, 関連の施設についても, 国際標準としての男女共同参画の観点から整備を進めて います。

高専機構は, 女性の活躍の重要性が今後益々増加する ことを確信して, 多様な組織との連携協力のもと, 特に, 科学技術分野で活躍する理工系人財において「男女共同 参画」と言う言葉が無くなる社会を目指して活動を進め たいと考えています.

この当たり前の社会の実現に向けて, 女性教職員の皆 様の積極的なチャレンジも期待されるところです.リー ダーはもとより皆様が意識して取り組む以外に設定した 数值目標の達成はできません，逆に言えば，明確な意志 を持って取り組めば，いずれの数值目標の達成も可能で す. 国連のSDGs（Sustainable Development Goals）に も繋がる「性別に関わりなくその能力と自らの意志に基 づき, 社会の対等な構成員として, あらゆる分野の活動 に参画できる」活力ある社会の実現も可能であると確信 しています. 